\title{
Pollen morphology of the genera Irlbachia, Tachia, Voyria and Voyriella (Gentianaceae Juss.) found in the Reserva Florestal Adolpho Ducke (Amazonas, Brazil)
}

\author{
Marcos Gonçalves Ferreira ${ }^{1,3}$, Maria Lúcia $\mathrm{Absy}^{1}$ and Vânia Gonçalves-Esteves ${ }^{2}$
}

Recebido em 8/05/2012. Aceito em 18/07/2012

\begin{abstract}
RESUMO
(Morfologia polínica dos gêneros Irlbachia, Tachia, Voyria e Voyriella (Gentianaceae Juss.) ocorrentes na Reserva Florestal Adolpho Ducke (Amazonas, Brasil)). Foi realizado um estudo da morfologia polínica de espécies Gentianaceae Juss. ocorrentes na Reserva Florestal Adolpho Ducke, Manaus, Brasil. Os grãos de pólen das espécies estudadas variaram morfologicamente quanto à unidade polínica (tétrades ou mônades), ao tamanho (pequenos, médios e grandes), à forma (oblata, suboblata, oblata-esferoidal, esférica, prolata-esferoidal e prolata, à polaridade (heteropolar, isopolar ou subisopolar), à simetria (bilateral ou radial) e ao número e tipo de aberturas (3-colporados e 1-3 porados). Quanto à ornamentação, foram reconhecidos grãos de pólen com sexina psilada nas espécies de Voyria, microrreticulada em Voyriella parviflora e reticulada heterobrocada em Tachia grandiflora e Irlbachia alata. A exina em I. alata mostrou grande variação na forma e tamanho dos lumens além da formação de clavas de tamanhos variados em áreas de mesocolpo e apocolpo. Em Tachia grandiflora, além de colpos longos, a exina heterobrocada apresentou um aumento do lúmen, em regiões do mesocolpo, diminuindo, consideravelmente, nas áreas do apocolpo. Nas espécies de Voyria, os grãos de pólen mostraram diferença quanto à forma, polaridade e ao número de aberturas, ocorrendo esferoidais, isopolares e 3-porados em Voyria spruceana; prolata/oval, heteropolares e 1-porados em Voyria tenella e oblato/elíptico (reniforme), heteropolares e 2-(3) porados em Voyria aphylla e Voyria caerulea. A variação na morfologia polínica e características exclusivas do gênero têm sugerido que Voyria seja tratada como um táxon único dentro de Gentianaceae.
\end{abstract}

Palavras-chave: Espécies neotropicais, Floresta amazônica, Palinologia, Taxonomia

\begin{abstract}
(Pollen morphology of the genera Irlbachia, Tachia, Voyria and Voyriella (Gentianaceae Juss.) found in the Reserva Florestal Adolpho Ducke (Amazonas, Brazil)). A pollen morphology study of the Gentianaceae Juss. of Reserva Florestal Adolpho Ducke (Manaus, Brazil) was performed. The pollen grains of the studied species varied morphologically in their pollen units (tetrads or monads), size (small, medium and large), shape (oblate, suboblate, oblate spheroidal, spheroidal, prolate spheroidal and prolate), polarity (heteropolar, isopolar or subisopolar), symmetry (bilateral or radial) and number and type of aperture (3-colporate and 1-3porate). In relation to ornamentation, pollen grains had a sexine that was psilate in the Voyria species, microreticulate in Voyriella parviflora and reticulate heterobrochate in Tachia grandiflora and Irlbachia alata. The exine in I. alata showed great variability in the size and shape of the lumina, in addition to clavae of various sizes in the mesocolpium and apocolpium areas. In Tachia grandiflora, besides to long colpi, the heterobrochate exine demonstrated an increase in the lumina in the mesocolpium areas that decreased considerably in the apocolpium areas. In the species of Voyria, the pollen grains showed differences in shape, polarity and the number of apertures, which were spherical, isopolar and 3-porate in Voyria spruceana; prolate/oval, heteropolar and 1-porate in Voyria tenella; and oblate/elliptical (reniform), heteropolar and 2(3)-porate in Voyria aphylla and Voyria caerulea. The variations in pollen morphology and the peculiar characteristics of the genus suggest that Voyria should be treated as a unique taxon within Gentianaceae.
\end{abstract}

Key words: Amazon forest, neotropical species, Palynology, Taxonomy

\footnotetext{
${ }^{1}$ Instituto Nacional de Pesquisas da Amazônia, Departamento de Botânica, Laboratório de Palinologia, Manaus, AM, Brasil

${ }^{2}$ Universidade Federal do Rio de Janeiro, Museu Nacional, Departamento de Botânica, Laboratório de Palinologia, Rio de Janeiro, RJ, Brasil

${ }^{3}$ Autor para correspondência: mgfbio@yahoo.com.br
} 


\section{Introduction}

Gentianaceae Juss. comprise approximately 80 genera and 1,000 species, distributed in six tribes, with a wide distribution in deserts, savannas, grasslands, forests and tundra (Struwe \& Albert 2004). The species of this family range from small herbs to shrubs, to vines or trees, with some saprophytic representatives. The inflorescences are dichasia, rarely racemose, or solitary flowers, which may be yellow, pink or blue. The family Gentianaceae is represented mainly in temperate and tropical mountain regions (Maas \& Maas 2005).

In Brazil, this family comprises 28 genera and 100 species (Souza \& Lorenzi 2008). In the Adolpho Ducke Forest Reserve, which is one of the Amazonian areas with a well-known flora, it is estimated that there are four genera and eight species of Gentianaceae; one species each of Irlbachia, Tachia and Voyriella and five species of Voyria. However, according to Maas \& Maas (2005), the genus Voyria is represented by four species, totaling seven species, which corroborates the number of species described in the book Flora da Reserva Ducke. The genera Irlbachia and Tachia are, respectively, shrubs ranging from $1 \mathrm{~m}$ to $3 \mathrm{~m}$ and upright herbs up to 1 $\mathrm{m}$ tall. The genera Voyria and Voyriella are saprophytic herbs less than $30 \mathrm{~cm}$ in height (Ribeiro et al. 1999).

Neotropical species are the most diverse in the Gentianaceae Juss. regarding pollen type (monads, tetrads or polyads), fruits (capsules or berries), flowers (hypocrateriform, urceolate or campanulate), anthers (versatile, basifixed, dorsifixed, curved or straight) and habit (herbs, shrubs or trees) (Struwe \& Albert 1998). Pollen morphology and morphological and cytological characteristics have been considered important in taxonomic studies of many Gentianaceae genera (Raynal 1967; Nilsson 1969); however, Gilg (1895) published a classification of tribes and subtribes based primarily on palynological features. This classification was later supported by Kohler (1905). However, Struwe et al. (2002), in a comparative study using phylogenetic analysis of molecular data and other characteristics, including morphology, revealed certain differences in the delineation of the Gentianaceae tribes and subtribes. Recently, few studies have been conducted about pollen morphology, phylogenetic and taxonomic implications of this group (Crespo \& Ferreira 2006, Pire \& Dematteis 2007, Chassot \& Hagen 2008, Via de Pico \& Dematteis 2010).

The present study is a morphological characterization of the pollen grains of seven species of Gentianaceae that are found in the Reserva Florestal Adolpho Ducke and may contribute to taxonomic studies as well as expand the palynological database of the Amazon.

\section{Materials and methods}

The pollen samples were obtained from herbarium specimens at the Instituto Nacional de Pesquisas da Amazônia (INPA), which represented seven species distributed in three genera found in the Reserva Florestal Adolpho Ducke - RFAD (Fig. 1). The Reserve is located north of the city of Manaus ( $\left.3^{\circ} 05^{\prime} \mathrm{S}, 60^{\circ} 00^{\prime} \mathrm{W}\right)$ in the state of Amazonia (AM). It covers an area of 10,000 ha. of upland forest or dense tropical forest, according to the RADAM-BRASIL classification. The Ducke Reserve has an extremely diverse flora, with approximately 1,000 tree species that are often 30 to $35 \mathrm{~m}$ tall or emergent trees that reach up $45-50 \mathrm{~m}$. The regional climate is classified as Afi (Köppen), with an average temperature of $26^{\circ} \mathrm{C}\left(39^{\circ} \mathrm{C}\right.$ maximum and $19^{\circ} \mathrm{C}$ minimum). Annual rainfall ranges from 1,900 to 2,300 mm, with a rainy season occurring from December to May and a dry season from June to November. The ombrophilous vegetation cover has a uniform canopy with an average height of $32 \mathrm{~m}$. The topography consists of plateaus cut by streams, forming floodplains in certain areas, with the majority of the springs located within the RFAD. The soils are derived from marine sediments of the tertiary Barreiras group. They represent a continuum of clayey oxisols in the crests, becoming sandier with increasing inclination and decreasing altitude. In the lowlands, the mineral fraction is almost pure sand (Baccaro et al. 2008).

The pollen grains were acetolysis according to the method described by Erdtman (1960) and were morphometrically evaluated with an ocular micrometer in the Laboratory of Palynology (INPA), photographed under a light microscope (LM) (Zeiss) at 1,000x magnification (immersion) and measured according to Erdtman (1952).

Analyzed material: Irlbachia alata Aubl. Maas: BRAZIL, Amazônia, Manaus, 17/XI/1999, fl., M. André 201849 (INPA). Tachia grandiflora Maguire \& Weaver: BRAZIL, Amazônia, Manaus, 29/I/2001, fl., L.F.O. Coelho 208096 (INPA). Voyria caerulea Aubl.: BRAZIL, Amazônia, Manaus, 13/V/1994, fl., A. Vicentini 210712 (INPA). Voyria tenella Hook.: BRAZIL, Amazônia, Manaus, 11/VI/1958, fl., E. Ferreira 6492 (INPA). Voyria spruceana Benth.: BRAZIL, Amazônia, Manaus, 22/IX/2003, fl., M.C. Souza \& E.N. Assis 213320 (INPA). Voyria aphylla (Jacq.) Pers.: BRAZIL, Amazônia, Manaus, 03/III/1994, fl., J.E.L.S. Ribeiro;

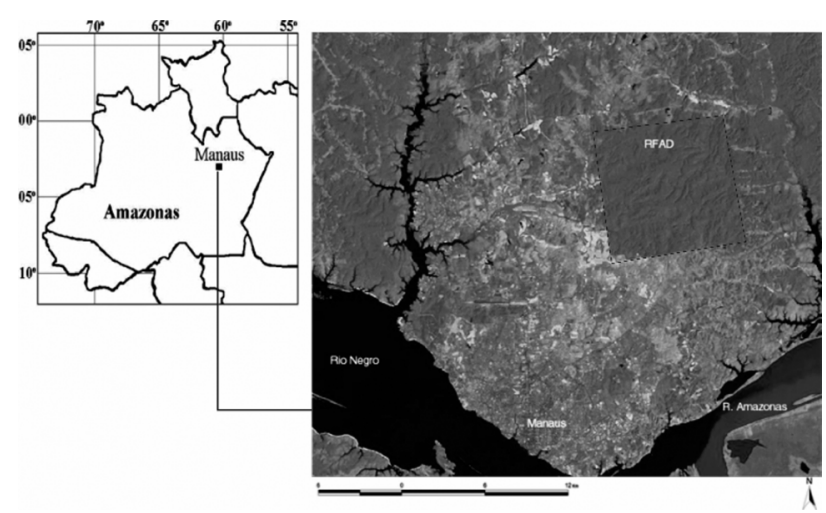

Figure 1. Reserva Florestal Adolpho Ducke (RFAD), located north of the city of Manaus, in the state of Amazonas (AM). (Source: Siglab/INPA). 
A. Vicentini; M.J.G; E.C. Pereira 210699 (INPA). Voyriella parviflora (Miq.) Miq.: BRAZIL, Amazônia, Manaus, 20/ IV/1961, fl., L.F.O. Coelho \& W. Rodrigues 8905 (INPA).

To obtain the electron micrographs, the anthers were ruptured under a stereomicroscope, and the pollen grains were spread on double-sided carbon tape and then attached to numbered stubs. The material was transferred to a vacuum pump and coated with a thin layer of palladium gold for three minutes. Subsequently, the pollen grains were analyzed by scanning electron microscopy (SEM) with a Zeiss DS M960 microscope (at the Hertha Meyer Laboratory of Cellular Ultrastructure of the Institute of Biophysics, Universidade Federal do Rio de Janeiro, UFRJ) and a Jeol, JSM 6390 microscope (at the Department of Invertebrates of the Museu Nacional, UFRJ).

For the pollen grains in monads, 25 measurements were recorded of the polar diameter $(\mathrm{P})$ and the equatorial diameter (E) in the equatorial view and, when possible, 10 measurements were recorded of the equatorial diameter and apocolpium side in the polar view. The same number of measurements was made for the pollen grains in tetrads. Ten measurements were made for the exine layers and the aperture dimensions.

From these measurements, the arithmetic means $(\bar{x})$, mean standard deviations $(s \overline{\mathrm{x}})$, sample standard deviations (s), coefficient of variation (CV\%) and confidence intervals (CI\%) were calculated. The adopted pollen terminology is in accordance to the glossary in Punt et al. (2007). In relation to the shape, in addition to the classes proposed by Erdtman (1952), peculiar forms used by Nilsson \& Skvarla (1969) were considered for some species of the genus Voyria. The sequence of the pollen descriptions for pollen grain size and shape was based on Barth \& Melhem (1988).

\section{Results}

Based on the LM and SEM observations, the pollen grains presented morphological differences among the genera of Gentianaceae found in the Reserva Florestal Adolpho Ducke. In general, the pollen grains were tetrahedral tetrads in Irlbachia and monads in the other genera, which ranged from small to large and had a reticulate, microreticulate or psilate exine. The apertures also varied, with the occurrence of 1-4-porate and 3-colporate. The pollen of the genus Voyria (represented by four species in this study) also showed differences in the shape (oblate, oblate spheroidal, and prolate) with specific variations (elliptical/reniform and ovoid), number of apertures (1-4-porate) and size (small and medium) (Tab. 1). However, all species of this genus were psilate without variations in the exine measurements (Fig. 2, 3; Tab. 2).

Irlbachia alata (Aubl.) Maas - Pollen grains form tetrahedral tetrads and acalymmate $(74.92 \pm 4.2 \mu \mathrm{m})$. The monads forming tetrads are of medium size, heteropolar with radial symmetry, have a triangular to circular amb and suboblate shape (Table 1), are 3-porate, reticulate exi- ne, heterobrochate, showing sinuous muri and with little difference between nexine and sexine (Table 2), presenting clavae grouped into mesocolpium and apocolpium regions, with an increase of lumina in the monads. Under LM, the apertures are irregular and described as being pores. Under SEM (Figure 3a-c), as have been used non-acetolysed pollen grains, the apertures were considered, coaperturate, showing a fusion between the monads and formation of a short colpus, imperceptible under LM (Figure $2 \mathrm{a}, \mathrm{b}$ ). The exine is thick, and the sexine is thicker than the nexine.

Tachia grandiflora Maguire \& Weaver - Pollen grains are medium sized, radial symmetry, prolate spheroidal, with a very small polar area, subtriangular (Tab. 1), and 3 -colporate, with very long colpi, circular endoapertures, and have reticulate exine and heterobrochate with the nexine slightly thicker than the sexine (Tab. 2). The reticulum lumina decrease in diameter near the apertures and polar area. Under LM, the exine appears thicker internally to the endoaperture. Under SEM of the acetolysed grains, the heterobrochate reticulum, narrow straight muri, apparent columellae and lumina with undulated surfaces and possible granulations were clear (Fig. 2c-f, 3d-f).

Voyria aphylla (Jacq.) Pers. - Pollen grains small, subisopolar, have bilateral symmetry, oblate shape (elliptical/ reniform), are 2(-1)-porate with a psilate surface and have exine without an apparent division between sexine and nexine (Tab. 2); however, they are thicker in the pore area, characterized by the presence of the annulus (Fig. 2g). Under LM, 2-porate (Fig. 2g, h) and, rarely, 1-porate pollen grains were found. The SEM highlighted aspects of the psilate exine and its characteristic elliptical (reniform) shape (Fig. 3g).

Voyria caerulea Aubl. - Pollen grains small, subisopolar have bilateral symmetry, oblate shape (elliptical/reniform), are 2(-3)-porate with a psilate surface, have exine without an apparent division between sexine and nexine (Tab. 2) and are thicker in the pore region forming the annulus. Under LM, in addition to 2-porate pollen grains (Fig. 2i), 3 -porate grains were also observed, albeit rarely. The SEM highlighted its irregular elliptical shape (reniform) and psilate surface (Fig. 3h).

Voyria spruceana Benth. - Pollen grains small, isopolar, have radial symmetry, with circular amb and an oblate spheroidal shape (Tab. 1), and are 3-(4)-porate with a psilate surface and sexine as thick as the nexine (Tab. 2). Under LM, in addition to the 3-porate grains (Fig. $2 \mathrm{j}$ ), rare 4-porate pollen grains were also observed. The SEM shows the psilate surface of the pollen grain and the characteristics of its semicircular shape (Fig. 3i).

Voyria tenella Hook. - Pollen grains medium-sized, heteropolar, prolate shape (irregular ovoid) (Tab. 1), are 1-porate with a psilate surface and have exine without an apparent division between sexine and nexine (Tab. 2). LM clearly shows the internal contents in addition to its shape and the presence of a single pore (Fig. 2k). SEM recorded details of its psilate surface (Fig. 3j). 

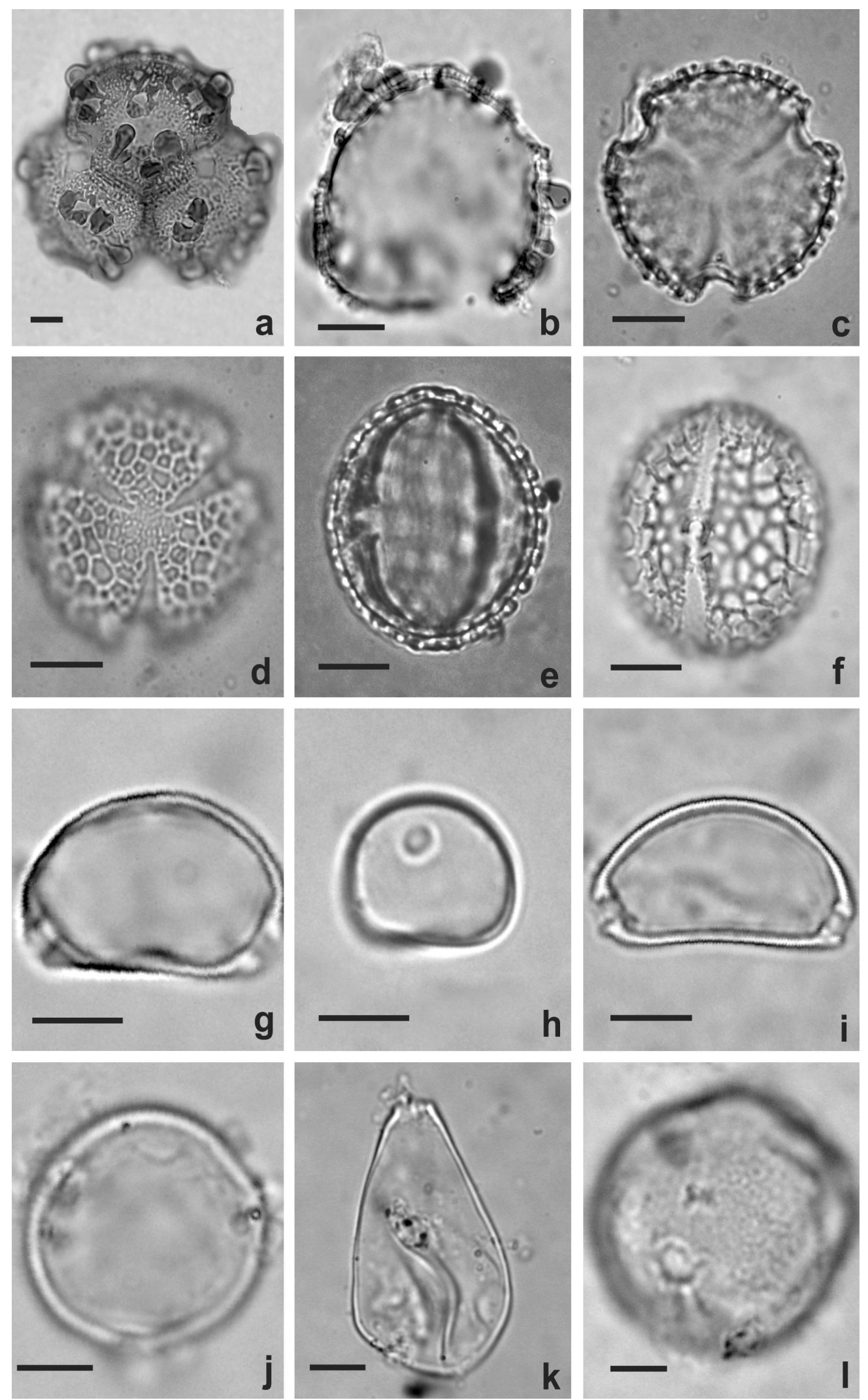

Figure 2. Optical photomicrographs of Gentianaceae pollen grains found in the Reserva Florestal Adolpho Ducke. a, b. Irlbachia alata - a. general appearance; b. tetrad-forming pollen grain in optical section. c-f. Tachia grandiflora - polar view: c. optical section; d. surface, equatorial view: e. optical section f. aperture. g, h. Voyria aphylla - equatorial view: g. optical section, h. aperture. i. Voyria caerulea - equatorial view, optical section. j. Voyria spruceana - polar view, optical section. k. Voyria tenella - equatorial view, aperture. l. Voyriella parviflora - equatorial view, aperture. (a-f bar $=10 \mu \mathrm{m} ; \mathrm{g}-\mathrm{l}=5 \mu \mathrm{m})$. 
Voyriella parviflora (Miq.) Miq. - Pollen grains small, isopolar, have radial symmetry, a spheroidal shape and triangular amb (Tab. 1) and are 3-colporate, with long and thin colpi with a small polar area (Apocolpium index-AI), circular endoaperture, a thick margin, microreticulate heterobrochate exine, with the sexine and nexine showing the same thickness (Tab. 2). The SEM of non-acetolysed pollen grains highlighted the long and thin colpus and sexine microreticulate with smaller lumina near the poles (Fig. 2l, 3k, l).

\section{Pollen key to the species of Gentianaceae found in the Floretal Adolpho Ducke Reserve:}

1. Pollen grains in tetrahedral tetrads

Irlbachia alata

1. Pollen grains in monads

2. Colporate pollen grains

3. Prolate spheroidal pollen grains, sexine reticulate

Tachia grandiflora

3. Spheroidal pollen grains, sexine microreticulate

2. Porate pollen grains

4. Monoporate pollen grains Voyriella parviflora

4. Pollen grains with more than one pore

5. Subisopolar pollen grains, 2-(3) or 2-(1)-porate

5. Isopolar pollen grain, 3-(4)-porate.

Voyria tenella

Voyria caerule and Voyria aphylla ..Voyria spruceana

Table 1. Measurements $(\mu \mathrm{m})$ of Gentianaceae pollen grains found in the Adolpho Ducke Forest Reserve. (P) polar diameter, $(\mathrm{E})$ equatorial diameter, $(\overline{\mathrm{x}})$ arithmetic mean, $(s \overline{\mathrm{x}})$ standard deviation, $(\mathrm{s})$ sample deviation, $(\mathrm{CV})$ coefficient of variation and $(\mathrm{CI})$ confidence interval $(\mathrm{n}=25)$.

\begin{tabular}{|c|c|c|c|c|c|c|c|c|c|}
\hline \multirow{2}{*}{ Species } & \multicolumn{4}{|c|}{ Polar diameter } & \multicolumn{4}{|c|}{ Equatorial diameter } & \multirow{2}{*}{$\mathrm{P} / \mathrm{E}$} \\
\hline & $(\overline{\mathrm{x}} \pm \mathrm{s} \overline{\mathrm{x}})$ & s & $\mathrm{CV} \%$ & CI (95\%) & $(\overline{\mathrm{x}} \pm \mathrm{s} \overline{\mathrm{x}})$ & s & $\mathrm{CV} \%$ & CI (95\%) & \\
\hline Irlbachia alata & $(35.6 \pm 0.58)$ & 2.9 & 8.1 & $(34.3-36.8)$ & $(47.0 \pm 0.61)$ & 3.1 & 6.6 & $(45.7-48.2)$ & 0.77 \\
\hline Tachia grandiflora & $(33.9 \pm 0.35)$ & 1.8 & 5.3 & $(33.1-34.6)$ & $(33.5 \pm 0.22)$ & 1.1 & 3.3 & $(33.1-34.0)$ & 1.01 \\
\hline Voyria aphylla & $(9.4 \pm 0.16)$ & 0.8 & 8.5 & $(9.1-9.7)$ & $(14.2 \pm 0.18)$ & 0.9 & 6.3 & $(13.8-14.6)$ & 0.66 \\
\hline Voyria caerulea & $(13.6 \pm 0.18)$ & 0.9 & 6.6 & $(13.2-14.0)$ & $(21.7 \pm 0.28)$ & 1.4 & 6.4 & $(21.1-22.3)$ & 0.63 \\
\hline Voyria spruceana & $(15.3 \pm 0.17)$ & 0.8 & 5.2 & $(15.0-15.7)$ & $(15.7 \pm 0.12)$ & 0.6 & 3.8 & $(15.4-16.0)$ & 0.97 \\
\hline Voyria tenella & $(25.4 \pm 0.50)$ & 2.5 & 9.8 & $(24.4-26.4)$ & $(16.2 \pm 0.46)$ & 2.3 & 14.2 & $(15.3-17.1)$ & 1.57 \\
\hline Voyriella parviflora & $(17.7 \pm 0.36)$ & 1.8 & 10.2 & $(17.0-18.4)$ & $(17.7 \pm 0.28)$ & 1.4 & 7.9 & $(17.2-18.3)$ & 1.00 \\
\hline
\end{tabular}

Table 2. Average measures $(\mu \mathrm{m})$ of EDPV, AS, walls and apertures of Gentianaceae pollen grains found in the Reserva Florestal Adolpho Ducke. EDPV: Equatorial diameter in polar view; AS: Apocolpium side; AI: Apocolpium index $(\mathrm{n}=10)$.

\begin{tabular}{|c|c|c|c|c|c|c|c|c|c|c|c|}
\hline \multirow{2}{*}{ Species } & \multirow{2}{*}{ EDPV } & \multirow{2}{*}{ AS } & \multirow{2}{*}{ AI } & \multirow{2}{*}{ Exine } & \multirow{2}{*}{ Sexine } & \multirow{2}{*}{ Nexine } & \multicolumn{2}{|c|}{ Colpus } & \multicolumn{2}{|c|}{ Endoaperture } & \multirow{2}{*}{ Pore } \\
\hline & & & & & & & length & width & length & width & \\
\hline Irlbachia alata & - & - & - & 2 & 1.2 & 0.8 & - & - & - & - & 6.3 \\
\hline Tachia grandiflora & 34.1 & 5.9 & 0.17 & 2.3 & 0.9 & 1.3 & 26.4 & 3.6 & 2.4 & 2.4 & - \\
\hline Voyria aphylla & - & - & - & 1.0 & - & - & - & - & - & - & 1.0 \\
\hline Voyria caerulea & - & - & - & 1.0 & - & - & - & - & - & - & 1.5 \\
\hline Voyria spruceana & - & - & - & 1.0 & - & - & - & - & - & - & 1.9 \\
\hline Voyria tenella & - & - & - & 1.0 & - & - & - & - & - & - & 2.8 \\
\hline Voyriella parviflora & 17.6 & 5.0 & 0.28 & 1.0 & 0.5 & 0.5 & 16.2 & 0.9 & 1.0 & 1.0 & - \\
\hline
\end{tabular}

\section{Discussion}

Generally, Gentianaceae pollen grains found in the Florestal Adolpho Ducke Reserve showed many morphological variations, such as the following: grains in tetrads or monads; bilateral or radial symmetry; hetero-, iso- or subisopolarity; spherical, oval or elliptical (reniform) shape; and were 3-colporate and 1-3-porate. This corroborates previous findings that the neotropical species are the most diverse members of this family with respect to their pollen units (Struwe \& Albert 1998). The palynological study of Gentianaceae has always been closely associated with the taxonomy of the family and the subject of numerous discussions (Gilg 1895; Raynal 1967; Nilsson \& Skvarla 

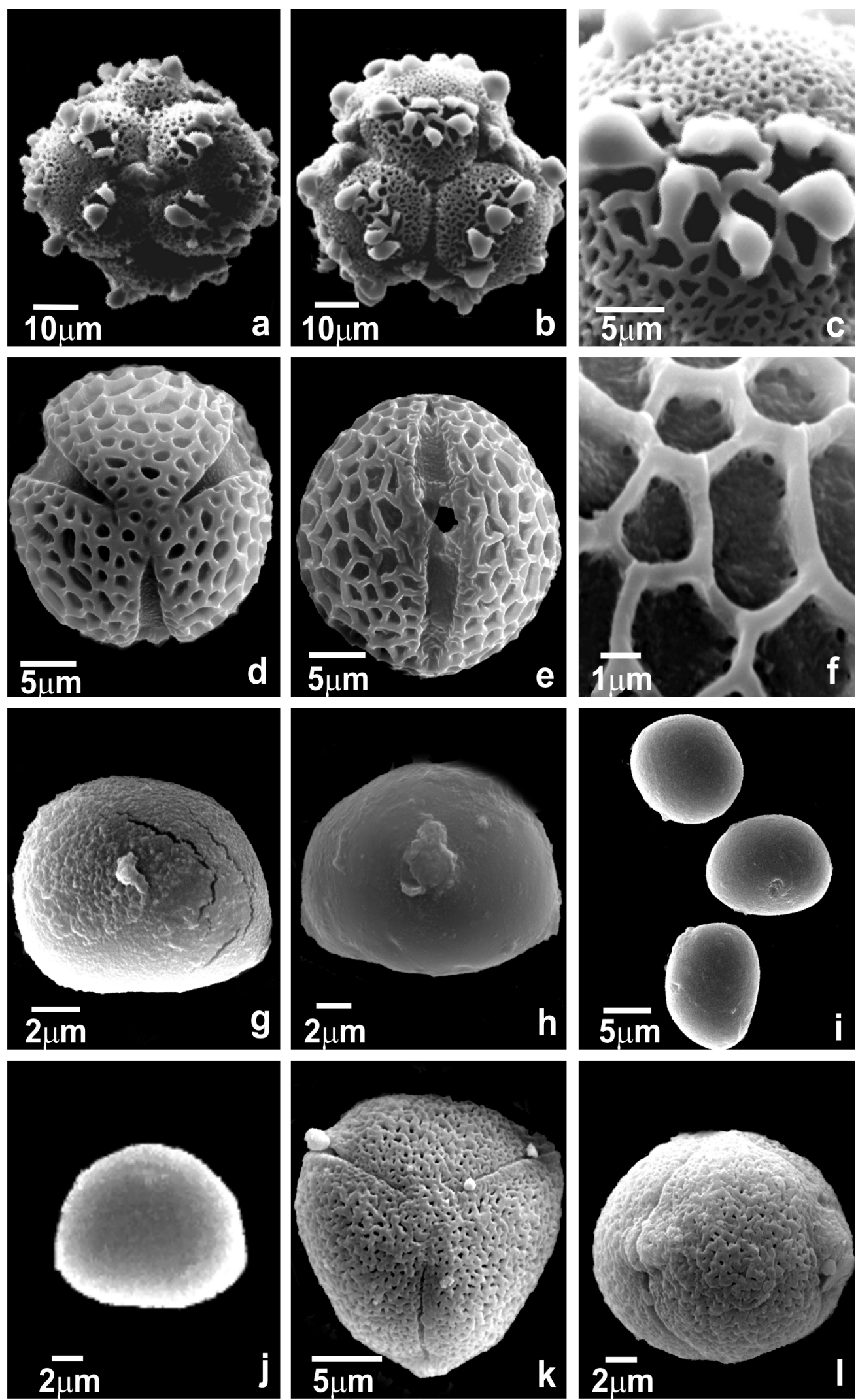

Figure 3. Electron micrograph SEM of Gentianaceae pollen grains found in the Reserva Florestal Adolpho Ducke. a-c. Irlbachia alata - a, b. general appearance; c. detail of ornamentation. d-f. Tachia grandiflora - d. polar view, apocolpium, e. equatorial view, aperture, f. surface detail. g. Voyria aphylla - equatorial view, general appearance and surface. h. Voyria caerulea - equatorial view, general appearance and surface. i. Voyria spruceana - equatorial view, general appearance. j. Voyria tenella - equatorial view, general appearance and surface. $k$, l. Voyriella parviflora - k. polar view, surface, l. equatorial view, aperture. 
1969). The main features in the classification of Gilg (1895) were pollen unit, size, shape and exine pattern. However, in a more recent study (Struwe \& Albert 2002), in addition to palynology, a more comprehensive approach including modern molecular analysis resulted in the rearrangement of tribes and subtribes within the Gentianaceae.

Maas \& Ruyters (1986) emphasized that the small size and microreticulate exine of Voyriella pollen, also described in the present study, would place it closer to the genus Curtia (Saccifolieae tribe) than to the tribe Leiphaimeae, as previously proposed by Gilg (1895). Grothe \& Maas (1984) and Nilsson et al. (2002) agreed with the assessment of the previously mentioned authors. The Voyriella parviflora description in the present study was in concordance with the description of Nilsson \& Skvarla (1969). These authors compared the pollen grains of Leiphaimos and Voyria and concluded that there was no difference in pollen morphology. Based on this observation, the authors considered Leiphaimos to be strongly related to the genus Voyria. These two genera were classified into different tribes (Leiphaimeae and Voyrieae, respectively), and according to Gilg (1985), Maas \& Ruyters (1986) and Albert \& Struwe (1997), due to their similar and peculiar pollen characteristics (reniform or oval pollen grain, 1-2-porate), Voyria was divided into two subgenera, Voyria subg. Voyria and Voyria subg. Leiphaimos. Despite these taxonomic changes, the position of Voyria in the Gentianaceae seems uncertain because its pollen characteristics are extremely different from all other genera of the family (Nilsson et al. 2002).

Nilsson \& Skvarla (1969) also found numerous variations within the genus Voyria, including pollen grains with bilateral and radial symmetry, of reniform and even spherical shapes, with variable aperture numbers (1-4-porate). In the present study, despite the variations indicated, V.aphylla and V. caerulea showed many similarities in shape, symmetry, number of apertures and sexine ornamentation, differing only in pollen grain size. However, $V$. tenella did not show a well-defined shape, being unique within the genus with oval, heteropolar, 1-porate pollen. Voyria spruceana showed spherical, isopolar, radially symmetric and clearly 3-porate grains, distinguishing it from the other species of the genus.

Irlbachia alata has pollen grains with characteristics very similar to Chelonanthus matogrossensis, as described by Nilsson et al. (2002), with an irregular sexine pattern and an increase in the lumina in the mesocolpium and polar areas. The pollen analysis of Irlbachia alata performed in the present study also showed clavae of irregular sizes grouped in the mesocolpium and apocolpium areas. Nilsson (1970; 2002) grouped various genera based on this transitional exine pattern to create the Ilrbachia complex.

Tachia grandiflora and Voyriella parviflora differed from the species of the other genera studied here because they exhibited colporate pollen grains. The two species differed in their sexine ornamentation (reticulate and microreticulate, respectively). In a study describing a new species of Tachia ( $T$. longipes) and palynologically comparing it with other species of the genus, Cobb \& Maas (1998) observed that, despite the morphological similarity, palynological characteristics (including the apocolpium index (AI) and the distinct luminal dimensions in the pollen grain) are relevant to the palynological characterization within the genus. This evaluation was not possible in the present study because only pollen grains of a single species of each genus were analyzed.

SEM studies partially revealed the detailed structures of the pollen grains. In I. alata, in the transition of the exine where were clavae of different sizes became evident, in addition to the revelation of a colpus, imperceptible in LM of acetolysed grains. The electron micrographs of Voyriella parviflora emphasized the exine microreticulate pattern, which is difficult to recognize under optical microscopy. Although the use of electron microscopy was important in this study, in the genus Voyria certain details could be observed better using optical microscopy, such as the observation of various views and details of the 3-porate grains that were not seen using SEM.

Despite the analysis of a small number of species from a limited area in the Amazon, the present study revealed palynological details of Neotropical species of Gentianaceae, corroborating previous studies and comparing them with other species within the group. The pollen similarities between the genera (Irlbachia and Chelonanthus) and differences within them (Voyria) suggest that in addition to molecular studies, detailed analyses of pollen characteristics of a larger number of species could significantly clarify the classification of the genera within the family.

\section{Acknowledgments}

The authors would like to thank the Instituto Nacional de Pesquisas da Amazônia/Ministério de Ciência e Tecnologia for providing the fellowship PCI/DTI to the first author (Proc. 680.001/2007-7); the Conselho Nacional de Desenvolvimento Científico e Tecnológico for the support given to the second author (Proc. 575747/2008-0 and 477127/2011-8) and the study grants to the third author; the Fundação de Amparo à Pesquisa do Estado do Rio de Janeiro for auxiliary support and the scanning electron microscopy technician MSc. We also thank Noêmia Rodrigues Gonçalves, of the Instituto de Biofísica, Universidade Federal do Rio de Janeiro, for producing the electron-micrographs of the pollen specimens.

\section{References}

Albert, V.A. \& L. Struwe. 1997. Phylogeny and classification of Voyria (saprophytic Gentianaceae). Brittonia 49(4): 466-479.

Baccaro, F.B.; Drucker, D.P.; Vale, J.; Oliveira, M.L.; Magalhães, C.; LepschGunha, N. \& Magnusson, W.E. 2008. A Reserva Ducke. Pp. 11-20. In: Oliveira, M.L.; Baccaro, F.B.; Braga-Neto, R. \& Magnusson, W.E. 2008. Reserva Ducke: A biodiversidade Amazônica através de uma grade. Manaus, Áttema Design Editorial. 
Barth, O.M. \& Melhem, T.S. 1988. Glossário ilustrado de palinologia. Campinas, UNICAMP.

Chassot P. \& von Hagen B.K. 2008. Pollen morphology of the Swertiinae (Gentianaceae): phylogenetic implications. Botanical Journal of the Linnean Society 157(2): 323-341.

Cobb, L. \& P.J.M. Maas. 1998. A new species of Tachia (Gentianaceae) from Suriname. Brittonia 50: 11-18.

Crespo, S.R.M. \& Ferreira, W.M. 2006. Morfologia polínica dos gêneros Curtia Cham. \& Schltdl. e Hockinia Gardner (Gentianaceae Juss.). Acta Botanica Brasilica 20(2): 273-284.

Erdtman, G. 1952. Pollen Morphology and Plant Taxonomy-Angiosperms. Stockholm, Almqvist \& Wiksell.

Erdtman, G. 1960. The acetolysis method. A revised description. Svensk Botanisk Tidskrift 54(4): 561-564.

Gilg, E. 1895. Gentianaceae. In: ENGLER, H.G.A. \& PRANTL, K.A.E. Die Naturlichen Pflanzenfamilien, Leipzig, 4(2):50-108.

Grothe, E. H. M. \& Maas, P.J.M. 1984. A scanning electron microscopic study of the seed coat structure of Curtia Chamisso \& Schlechtendal and Hockinia Gardner (Gentianaceae). Koninklijke Nederlandse Akademie van Wetenschappen 87(1):33-42.

Kohler, A. 1905. Der systematische Wert der Pollenbeschaffenheit bei den Gentianaceen. Mitteilungen aus dem botanischen Museum der Universität Zürich 25: 1-72.

Maas, H. \& Maas, P.J.M. 2005. Flora da Reserva Ducke, Amazonas, Brasil: Gentianaceae. Rodriguésia 56(86):169-173.

Maas, P.J.M. \& Ruyters, P. 1986. Voyria and Voyriella (saprophytic Gentianaceae). Flora Neotropica monograph 41. Bronx, The New York Botanical Garden.

Nilsson, S. 1970. Pollen morphological contributions to the taxonomy of $\mathrm{Li}$ sianthus L.s.lat.(Gentianaceae). Svensk Botanisk Tidskrift 64 (1): 1-43.

Nilsson, S. 2002. Gentianaceae: a review of palynology. Pp.: 377-497. In: Struve, L. \& Albert, V.A. (Ed.) Gentianaceae. Systematics and natural history. Cambridge, Cambridge University Press.
Struwe, L.; Kadereit, J.; Klackenberg, J.; Nilsson, S.; Thiv, M.; Hagen, K.B.Von. \& V.A. Albert, V.A. 2002. Systematics, character evolution, and biogeography of Gentianaceae, including a new tribal and subtribal classification. Pp: 21-309. In: Struve, L. \& Albert, V.A. (Ed.). Gentianaceae. Systematics and natural.

Nilsson, S. \& Skvarla. J.J. 1969. Pollen morphology of saprophytic taxa in the Gentianaceae. Annals Missouri Botanical Garden 56: 420-438.

Nilsson S.; Hellbom, M. \& Smolenski, W. 2002. A reappraisal of the significance of pollen in classifications of the Gentianaceae. Grana 41: 90-106.

Pire SM, Dematteis, M. 2007. Pollen aperture heteromorphism in Centaurium pulchellum (Gentianaceae). Grana 46(1): 1-12.

Punt, W.; Hoen, P. P.; Blackmore, S.; Nilsson, S. \& Le Thomas, A. 2007. Glossary of pollen and spore terminology. Review of Palaeobotany and Palynology 143: 1-81.

Raynal, A. 1967. Étude critique des genres Voyria et Leiphaimos (Gentianaceae) et revision des Voyria d'Afrique. Adansonia 2(7): 53-71.

Ribeiro, J.E.L.S.; Hopkins, M.J.G.; Vicentini, A.; Sothers, C.A.; Costa, M.A.S.; Brito, J.M.; Souza, M.A.D.; Martins, L.H.P.; Lohmann, L.G.; Assunção, P.A.C.L.; Pereira, E.C.; Silva, C.F.; Mesquita, M.R. \& Procópio, L.C. 1999. Flora da Reserva Ducke. Guia de Identificação das Plantas Vasculares de uma Floresta de Terra-firme na Amazônia Central. Manaus, Instituto Nacional de Pesquisas da Amazônia.

Souza, V.C. \& Lorenzi, H. 2008. Botânica Sistemática: Guia ilustrado para identificação das famílias de Angiospermas da flora brasileira, baseado em APG II. Nova Odessa, Instituto Plantarum.

Struwe, L. \& Albert, V. A. 1998. Lisianthius (Gentianaceae), its probable homonym Lisyanthus, and the priority of Helia over Irlbachia as its substitute. Cambridge. Harvard Papers in Botany 3(1):63-71.

Struwe, L. \& Albert, V. A. 2002. Gentianaceae: systematics and natural history. Cambridge, Cambridge University Press.

Struwe, L. \& Albert, V.A. 2004. Gentianaceae. Pp. 166-168. In: Smith, N.; Mori, S.A.; Henderson, A.; Stevenson, D.Wm. \& Heald, S.V. (Eds.). Flowering plants of the Neotropics. Princeton, Princeton University Press.

Via do Pico, G M. \& Dematteis, M. 2010. Meiotic behavior and pollen morphology variation in Centaurium pulchellum (Gentianaceae). Plant Systematics \& Evolution 290: 99-108. 